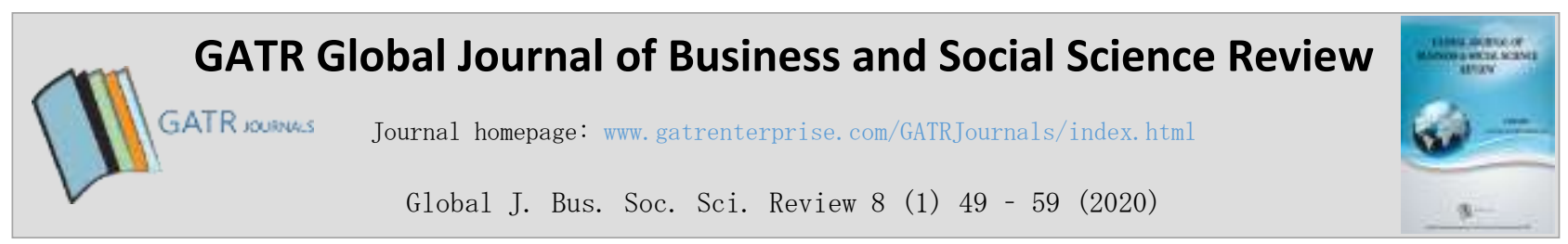

\title{
Local Government Unit Basic Services: Implementation and Assessment
}

\author{
Rosalie C, Leal $^{1 *}$, Orpha S. Sagubo ${ }^{2}$, Reynaldo M. Brutas ${ }^{3}$ \\ ${ }^{123}$ Isabela State University, San Andres San Mateo, Isabela,3318, Philippines
}

\begin{abstract}
Objective - Local Government Units (LGUs) play a significant role in the development of their constituents. Basic services should be their main priority in order to implement these services to a high standard. Hence, this study aims to assess the level of implementation of basic services in San Mateo, Isabela, taking into account the profile of the respondents, their perception on the implementation of basic services and good governance, significant differences in their perceptions, and problems encountered in the implementation process.

Methodology/Technique - The data collected was measured and analysed using the Social Sciences Statistical Package (SPSS).

Finding - The results show that the respondents (which were grouped into 4) vary in their perceptions on the implementation of the basic services; however, the level of implementation was high. Moreover, the 4 dimensions of good governance recorded a very satisfactory level of implementation. These findings imply that the mechanisms used in the delivery of basic services are effective and responsive. Thus, the model used by the LGU San Mateo may be shared with other municipalities to achieve quality delivery of basic services.
\end{abstract}

Type of Paper: Empirical.

Keywords: Basic Services; Perceptions; Level of Implementation; Local Government Unit; Public Service.

Reference to this paper should be made as follows: Leal, R.C; Sagubo, O.S; Brutas, R. M. (2020). Local Government Unit Basic Services: Implementation and Assessment, Global J. Bus. Soc. Sci. Review, 8(1): 49 - 59. https://doi.org/10.35609/gjbssr.2020.8.1(6)

JEL Classification: H7, H70.

\section{Introduction}

The role of LGU is essential in delivering basic services. Therefore, this study is grounded on the concept that the implementation of basic services is connected with good governance dimensions. The need to evaluate the implementation of basic services is also an important avenue to guide leaders in order to achieve its Mission, Vision and Objectives. According to Bondi and Wiles, as cited by Piggingnon-Francisco (2008), evaluation is a positive process which helps to inspire the various components of the system, keeping in mind the essential interrelationship involved within it.

\footnotetext{
* Paper Info: Revised: January 13, 2020

Accepted: March 31, 2020

* Corresponding author: Rosalie C, Leal

E-mail: rosalie.c.leal@isu.edu.ph

Affiliation: Isabela State University, San Andres San Mateo, Isabela,3318, Philippines
} 
Evidently, a study on decentralization by the World Bank identified a myriad of problems that local governments and communities may confront. Among these problems are: "uncertain access to a potable water and electricity, declining literacy rates, environmental degradation, rising unemployment rates, lack of low-cost housing, and unreliable police and fire department services." These problems are crucial to any community and its constituent. In cases where immediate actions are not taken to address these problems, there is a risk of failure to adhere to what is stated in the Local Government Code of 1991 which spells out what basic services should be given to the community.

For this reason, San Mateo, Isabela is not free from the practice of the Local Government Code. It is therefore essential to raise crucial questions about how the leaders have been running the municipality over the years, and how far the municipality has developed. These matters are indicative of how well basic services have been implemented in San Mateo, and to what extent these basic services attuned to their advocacy to become an Agro-Ecological City in the Philippines.

The step of San Mateo towards a promising Agro-Ecological City requires a certain degree of responsibility and standard. Being a multi-awarded municipality has no absolute guarantee that the basic services of San Mateo, or any municipality, are optimally delivered, more so with visions that entail bigger responsibilities. It is necessary to assess the level of implementation of the basic services of San Mateo, Isabela in Agriculture, Infrastructure, Health, Environmental, Tourism, Education, and Social. This not only measures the municipality's adherence to the Code of 1991 as well as the steps it has taken to further improve its multi-dimensional role in good governance. It also aims to help San Mateo cope with the constantly changing world: challenges brought about by urbanization, advanced technology adoption, unpredictable changes of environment brought about by climate change, the increasing population, and others that are contributory to the rise and fall of a community.

Leaders, who are considered servants of the people, hold the power to help the people, the ones where true power comes from. Thus, assessing the performance of the leaders of San Mateo in basic services will provide data or point of reference for more viable programs and projects and eventually winning the trust of the citizens. Furthermore, this can also be a basis for the development of policy, institutional or financial analyses, reforms and recommendations to improve the basic services being rendered to the citizens of San Mateo. Ultimately, the result of this study will provide LGUs standards or models in the delivery of basic services, leading to enhanced and developed communities.

\section{Related Literature}

Generally, the job and responsibility of the government is to determine the kind and level of service that must be rendered to the citizens to fit into the systems. It would be beneficial for them if the government has a systematic process that is strongly committed in providing quality service, as government primary objective is to lessen the cost impact of compliance in government policies prior to the operations or existence of any business. Directing business to appropriate channels and the integration of necessary instruments to complete the process put businesses in an easy start-up. These improvements can alter the negative attitudes the business community is holding in any public services (Vincent \& Zhu, 2004). This justification has led the government to become more customer-focused. In order to respond to this need, the authority may need to adapt business attitude towards customers, to view citizens differently, this time as clients and customers (Brilliantes, 2003).

In many places across the world, business develops at a rapid pace, not only because of the desire to raise the standard of living, but also because it has undeniably been a massive factor in the growth of a local's economy. There are multi-national industries, technology and services industries, such as BPOs and shopping malls which are receiving high demands from the public.

Establishing a business requires compliance with a strict legal regime; local governments should make an effort to systematize the processing of requirements. For instance, the Business Permit and Licensing Division- Business One Stop Shop (BPLD-BOSS) aims to streamline the process of obtaining a business 
permit with systematic implementation. The Local Government Units of Angeles and San Fernando are 2 of the pioneers of this business process in Region 3. This program is a flagship project of the Central Luzon Growth Corridor Foundation Incorporated (CLGCFI), in cooperation with the Department of Trade and Industry (DTI) and the Department of Interior and Local Government (DILG).

Tax computations, processing the applications, monitoring quality through collecting client's feedback and opinions, internal monitoring systems and organizational development are all steps undertaken prior to the issuance of a permit to run a business. However, there is a more simplified registration which is more economical in terms of steps, procedures, process time, and cost. The quality of this process is based on ISO 9001:2008 or the International Organization for Standardization which is being used by the LGU Quality Management Systems (QMS) Office.

Satisfaction requires a moment of truth, an experience whether expectations or satisfactions have been met by the service given. According to Lovelock and Wirtz (2008), satisfaction is a positive disconfirmed expectation, while Palmer (2011) states that it is a post consumption experience that compares perceived quality with expected quality. Moreover, Baran, Galka and Strunk (2008) argue that satisfaction can be broadly characterized as a post-purchase evaluation of product quality given pre-purchase expectations.

Satisfaction may vary based on customers' tastes and preferences. This classifies satisfaction as either transaction-specific or cumulative satisfaction. Taiwo, Salim and Downer (2011) state that customers evaluate their satisfaction on their first try of a service, while for repeated customers, they evaluate their satisfaction from their first to most recent experience.

From the government perspectives, surveys, opinions and perceptions will help the government obtain the best available information about customers' satisfaction. For instance, public agencies ask questions directly about how the service was delivered during actual encounters (MORI Review, 2002). However, this is contrary to the claim of EUPAN or the European Public Administration Network (2008), who believe that citizen survey satisfaction assessed the appropriation of certain activities or its irrelevance in achieving the bottom line. However, Bourgogne (2007) still argues that understanding the impact of alternative options whether these alternatives would or would not meet the customers' needs and reduce the risk, if not risk-free, of unforeseen consequences, is helpful.

Manzin, Zurga and Mrak (2012) cite the different relationships between the State and customers of administration (Shand \& Amberg, 1996). Customers recognize that they have clear obligations towards tax administrations, but, by large, they expect a certain level of service or help that would aid them in carrying out their duties. Customers are aware of the applicable legal obligations; they are aware that businesses are subject to inspection, but customers expect suitable and prompt activities by regulators or government. With these, government then needs to guide and inform customers how they will carry out their obligation in the process of providing the service.

As a response, the government must seek ways to improve the services they provide in order to meet the expectations of their constituents. It should adapt and update its processes in administering public service in order to build trust towards its consumers. Bal et. al. (2011) states that people with low levels of trust will be more easily triggered by negative events. Cheema and Popovski (2010) believe that this would be gradual and troublesome to recover the trust in public policy and institutions. Obviously, it will negatively affect or influence their credibility as public servants.

There is a need for the government to revitalize local services, increase administrative performance, and develop competitive, knowledgeable local officials and personnel. Changes and development in the commercial sector and advancement of technology have also created pressure on the public sector, as constituents are more interested with a fast and reliable performance when availing the type of service process the government is performing.

Moreover, good governance is another key factor in the delivery of basic services. It has 8 major characteristics namely, participatory, consensus-oriented, accountable, transparent, responsive, effective and 
efficient, equitable, and inclusive. If these characteristics of good governance are carried out truthfully, there is assurance that corruption is minimized, the views of minorities are taken into account, and that the voices of the most vulnerable in society are heard in decision-making. With all of these, the government becomes responsive to the present and future needs of society.

Accordingly, the delivery of public services must be prompt and adequate to citizens' needs. Cumbersome government procedures slow down the delivery of public service and increase transaction costs. The same arduous government processes also provide opportunities for corruption, given the natural tendency to avoid bureaucratic red tape. The Anti-Red Tape Act (ARTA) of 2007 requires national departments, agencies, and LGUs to set up their respective service standards known as Citizen's Charters (CCs), to simplify procedures and to facilitate transactions. As of 30 August 2010, 74\% of agencies $(4,253$ of 5,716) nationwide had complied with the drafting and promulgation of the CCs. As a means to develop citizens' awareness of their rights vis-à-vis government and encouraging citizens' criticisms when aggrieved, this is one step towards cutting red tape and reducing corruption.

\section{Research Methodology}

This study was conducted among the 33 barangays in the Municipality of San Mateo, Isabela. The questionnaire was answered by 4 groups of respondents which include 11 Elective Municipal Officials, 14 Heads of Offices, 33 Barangay Captains, and 389 Beneficiaries of the basic services, with a total of 447 respondents. Descriptive and inferential methods of research are used. The descriptive approach was used to assess the respondents ' understanding of the level of basic services delivery and good governance. The inferential method was used to analyze the differences of the perceptions of the respondents on the level of implementation of basic services and good governance. The gathered data were treated statistically; frequency counts and percentages were used in determining the profile of the respondents. Weighted mean was used to describe the data with regard to the level of implementation of basic services, good governance, and problems encountered. Likert's System was utilized to derive the equivalents of the ratings of the different basic services and good governance indicators. One-way Variance Analysis (F-test) was used to assess if there were significant differences between the mean ratings of the 4 groups of respondents at a $5 \%$ level of significance.

\section{Results and Discussion}

Table 1. The Level of Implementation of Basic Services

Basic Services

\begin{tabular}{llcc} 
& & Grand Mean & QD \\
\hline 1. & Agricultural Support & $\mathrm{H}$ & 3.54 \\
2. Infrastructure & 3.73 & $\mathrm{H}$ \\
3. Health & 3.75 & $\mathrm{H}$ \\
4. Environmental Management & & $\mathrm{H}$ \\
& & 4.10 & $\mathrm{H}$ \\
5. Tourism & 3.90 & $\mathrm{H}$ \\
6. Educational Support & 3.69 & $\mathrm{H}$ \\
7. Social Services & 3.84 & $\mathrm{H}$ \\
\hline
\end{tabular}


The above table shows the summary of the perception of the respondents in terms of the level of implementation of basic services. Environmental Management manifests a grand mean of 4.10, followed by Tourism with a grand mean of 3.90, Social Services with a grand mean of 3.84, Health with a grand mean of 3.75, Infrastructure with a grand mean of 3.73, Educational Support with a grand mean of 3.69, and Agricultural Support with a grand mean of 3.54, the last among the 7 basic services

This means that LGU San Mateo implementer respondents perceived that environmental managements are their strongest points in terms of implemented programs and projects. This also means that beneficiary respondents appreciate the way the programs were implemented. Therefore, the finding validates the award of San Mateo as one of the best implementers of RA 9003 and "Walang Plastikan".

However, the findings on Agricultural Support which achieved the lowest mean negated the perceptions of the beneficiary respondents because Agriculture Support remains to be one of the priority programs of LGU as concretized by the award as "Mungo Capital of the Philippines Gawad Saka" award to some farmers. Therefore, it suggests that implementers must conduct an information campaign on the different programs and services, especially on Agriculture services.

Nevertheless, the 7 basic services rated by the respondents have a high level of implementation. This implies that various services are appreciated by the respondents as they feel the existence of these basic services.

Table 2. The Implementation of Basic Services on Good Governance

\begin{tabular}{|c|c|c|}
\hline Good Governance & $\begin{array}{c}\text { Overall } \\
\text { Mean }\end{array}$ & QD \\
\hline \multicolumn{3}{|l|}{ 1. Accountability and Transparency } \\
\hline & 3.57 & Very Satisfactory \\
\hline 2. Participation and Empowerment & 3.64 & Very Satisfactory \\
\hline 3. Effectiveness & 3.71 & Very Satisfactory \\
\hline 4. Management & 3.57 & Very Satisfactory \\
\hline & 3.62 & Very Satisfactory \\
\hline
\end{tabular}

Table 2 presents the respondents ' perceptions of the 4 areas of good governance where basic services are implemented. It is glaring that Effectiveness has the highest value of 3.71 or Very Satisfactory, followed by Participation and Empowerment with an overall mean of 3.62, while Accountability, Transparency, and Management tied with an overall mean of 3.57.

These findings mean that the respondents differ in their perceptions in terms of good governance. This implies that the variation may be attributed to other LGU resources such as "financial resources", as mentioned by Aldaba (2007), cited by Bueno (2011), which affect the "effectiveness in the delivery of social services". 
Table 3. Significant Differences on the Level of Implementation of Basic Services

\begin{tabular}{|c|c|c|c|c|c|c|c|c|c|c|c|c|}
\hline \multicolumn{13}{|c|}{ Respondents } \\
\hline \multirow[t]{2}{*}{ Basic Services } & \multicolumn{2}{|c|}{$\begin{array}{c}\text { Municipal } \\
\text { Elective } \\
\text { Officials }\end{array}$} & \multicolumn{2}{|c|}{$\begin{array}{l}\text { Head of } \\
\text { Office }\end{array}$} & \multicolumn{2}{|c|}{$\begin{array}{c}\text { Barangay } \\
\text { Captain }\end{array}$} & \multicolumn{2}{|c|}{$\begin{array}{c}\text { Beneficiari } \\
\text { es }\end{array}$} & \multicolumn{2}{|c|}{$\begin{array}{l}\text { Overall } \\
\text { Value }\end{array}$} & \multirow[t]{2}{*}{$\begin{array}{c}\mathbf{F} \\
\text { Value }\end{array}$} & \multirow[t]{2}{*}{$\begin{array}{c}\mathbf{P} \\
\text { Valu } \\
\mathbf{e} \\
\end{array}$} \\
\hline & $\begin{array}{c}\text { Mea } \\
\text { n }\end{array}$ & QD & Mean & $\begin{array}{l}\mathbf{Q} \\
\mathbf{D}\end{array}$ & Mean & $\begin{array}{l}\mathbf{Q} \\
\mathbf{D}\end{array}$ & Mean & $\begin{array}{l}\mathbf{Q} \\
\mathbf{D}\end{array}$ & Mean & $\begin{array}{l}\mathbf{Q} \\
\mathbf{D}\end{array}$ & & \\
\hline $\begin{array}{l}\text { 2. Agricultural } \\
\text { Support }\end{array}$ & 4.75 & $\mathrm{VH}$ & 4.19 & $\mathrm{H}$ & 4.04 & $\mathrm{H}$ & 3.44 & A & 3.54 & $\mathrm{H}$ & $\begin{array}{r}24.86 \\
3\end{array}$ & $.000 *$ \\
\hline 3. Infrastructure & 4.94 & VH & 4.42 & $\mathrm{H}$ & 4.22 & $\mathrm{H}$ & 3.62 & $\mathrm{H}$ & 3.73 & $\mathrm{H}$ & $\begin{array}{r}29.81 \\
2\end{array}$ & $.000^{*}$ \\
\hline 4. Health & 4.90 & VH & 4.81 & VH & 4.08 & $\mathrm{H}$ & 3.65 & & 3.75 & $\mathrm{H}$ & $\begin{array}{r}26.91 \\
2\end{array}$ & $.000 *$ \\
\hline $\begin{array}{l}\text { 5. Environmental } \\
\text { Management }\end{array}$ & 4.97 & VH & 4.80 & VH & 4.33 & $\mathrm{H}$ & 4.02 & $\mathrm{H}$ & 4.10 & $\mathrm{H}$ & $\begin{array}{r}15.23 \\
6\end{array}$ & $.000 *$ \\
\hline 6. Tourism & 4.95 & VH & 4.39 & $\mathrm{H}$ & 4.38 & $\mathrm{H}$ & 3.81 & $\mathrm{H}$ & 3.90 & $\mathrm{H}$ & $\begin{array}{r}16.97 \\
6\end{array}$ & $.000 *$ \\
\hline 7. Education Support & t 4.90 & $\mathrm{VH}$ & 4.91 & VH & 4.24 & $\mathrm{H}$ & 3.58 & $\mathrm{H}$ & 3.69 & $\mathrm{H}$ & $\begin{array}{r}23.68 \\
4\end{array}$ & $.000 *$ \\
\hline 8. Social Welfare & 4.95 & $\mathrm{VH}$ & 4.74 & $\mathrm{VH}$ & 4.41 & $\mathrm{H}$ & 3.72 & $\mathrm{H}$ & 3.84 & $\mathrm{H}$ & 20.920 & $.000 *$ \\
\hline $\begin{array}{l}\text { Averag } \\
\text { e }\end{array}$ & 4.91 & VH & $\begin{array}{l}4 . \\
61\end{array}$ & VH & 4.24 & $\mathbf{H}$ & 3.69 & $\mathbf{H}$ & 3.79 & $\mathbf{H}$ & & \\
\hline
\end{tabular}

* significant at .05 alpha

As shown in Table 3, all basic services have a probability value of 0.000 which is less than .05 . This establishes significant differences on the level of implementation of basic services. This means that it rejects the null hypothesis that there is no significant difference in the views of the 4 classes of respondents on the level of basic service implementation.

It also shows that Municipal Elective Officials perceived Environmental Management as Very High on the level of implementation with a mean value of 4.97, while beneficiary respondents rated at 4.02 or High. This confirms the consistency of their ratings with slight differences. The Head of Office respondents perceived Educational Support as the highest in terms of implementation at 4.91 or Very High, while the Barangay Captains perceived Social Services as the highest at 4.41 or High. Nonetheless, in the scores of the respondents are consistent that Agricultural Services rated the lowest with an overall average of 3.54 or high implementation point.

These findings mean that the 4 groups of respondents differ in their perception in the level of implementation, but they appreciate the spearheaded programs and projects. The findings may also mean that Municipal Elective Officials and Head of Office respondents have favorable responses in all the basic services, since they are the implementers. However, in relation to the Barangay Captain and Beneficiary respondents, their perceptions are slightly different with lower general mean values. Furthermore, the consistency of high ratings by the respondents is consistent with the stature of the Municipality as an awardee of the implementation of RA 9003.

The results of this study support the research of Malaluan (2001) and Reyes (2012) that there are significant differences in expectations between the different groups of respondents and the basic services of LGU. 
Table 4. Significant Differences on the Level of Implementation of Basic Services in terms of Good Governance

\begin{tabular}{|c|c|c|c|c|c|c|c|c|c|c|c|c|c|}
\hline \multicolumn{14}{|c|}{ Respondents } \\
\hline & \multirow[t]{2}{*}{ Basic Services } & \multicolumn{2}{|c|}{$\begin{array}{l}\text { Municipal } \\
\text { Elective } \\
\text { Officials }\end{array}$} & \multicolumn{2}{|c|}{$\begin{array}{l}\text { Head of } \\
\text { Office }\end{array}$} & \multicolumn{2}{|c|}{$\begin{array}{c}\text { Barangay } \\
\text { Captain }\end{array}$} & \multicolumn{2}{|c|}{$\begin{array}{c}\text { Beneficiari } \\
\text { es }\end{array}$} & \multicolumn{2}{|c|}{$\begin{array}{l}\text { Overall } \\
\text { Value }\end{array}$} & \multirow[t]{2}{*}{$\begin{array}{c}\mathbf{F} \\
\text { Value }\end{array}$} & \multirow[t]{2}{*}{$\begin{array}{c}\mathbf{P} \\
\text { Valu } \\
\mathbf{e} \\
\end{array}$} \\
\hline & & $\begin{array}{c}\text { Mea } \\
\mathbf{n}\end{array}$ & QD & Mean & $\begin{array}{l}\mathbf{Q} \\
\mathbf{D}\end{array}$ & Mean & $\begin{array}{l}\mathbf{Q} \\
\mathbf{D}\end{array}$ & Mean & $\begin{array}{l}\text { Q } \\
\text { D }\end{array}$ & Mean & $\begin{array}{l}\mathbf{Q} \\
\mathbf{D}\end{array}$ & & \\
\hline 1. & $\begin{array}{l}\text { Accountability \& } \\
\text { Transparency }\end{array}$ & 4.80 & $\mathrm{E}$ & 4.14 & VS & 4.14 & $\mathrm{VS}$ & 3.46 & 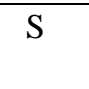 & 3.57 & VS & $\begin{array}{r}27.35 \\
4\end{array}$ & $.000^{*}$ \\
\hline 2. & $\begin{array}{l}\text { Participation and } \\
\text { Empowerment }\end{array}$ & 4.93 & E & 4.20 & VS & 4.25 & VS & 3.53 & VS & 3.64 & VS & $\begin{array}{r}27.69 \\
9\end{array}$ & $.000^{*}$ \\
\hline 3. & Effectiveness & 4.87 & $\mathrm{E}$ & 4.31 & VS & 4.37 & VS & 3.60 & VS & 3.71 & VS & $\begin{array}{r}25.67 \\
6\end{array}$ & $.000 *$ \\
\hline 4. & Mamgement & 4.84 & E & 4.41 & VS & 4.28 & VS & 3.45 & $\mathrm{~S}$ & 3.57 & VS & $\begin{array}{r}22.06 \\
5\end{array}$ & $.000^{*}$ \\
\hline & Average & 4.86 & $\mathbf{E}$ & 4.26 & VS & 4.26 & VS & 3.51 & VS & 3.51 & VS & & \\
\hline
\end{tabular}

* significant at .05 alpha

The data reveals the significant differences in the respondents' perceptions on the level of implementation of basic services in terms of good governance. The level of implementation of basic services in terms of Accountability and Transparency, Participation and Empowerment, Effectiveness, and Management all significantly differ among the 4 groups with probability values (p-value) less than 0.05 . This suggests that the null hypothesis of no significant difference in the views of the 4 classes of respondents on the extent of delivery of basic services is dismissed in terms of good governance.

This result suggests that, particularly in relation to Effectiveness and Accountability and Transparency, the 4 groups of respondents have similar views. This denotes that good governance is evident and practiced in the municipality. This further signifies that LGU San Mateo is compliant with the different dimensions of good governance in consonance with the strategic framework and challenges of good governance as indicated in the PDP (2011-2016).

Table 5. Problems Encountered in the Implementation of Basic Services

\begin{tabular}{|c|c|c|c|c|c|c|c|c|c|c|}
\hline \multicolumn{11}{|c|}{ Respondents } \\
\hline \multirow[t]{2}{*}{ Basic Services } & \multicolumn{2}{|c|}{$\begin{array}{c}\text { Municipal } \\
\text { Elective } \\
\text { Officials }\end{array}$} & \multicolumn{2}{|c|}{$\begin{array}{l}\text { Head of } \\
\text { Office }\end{array}$} & \multicolumn{2}{|c|}{$\begin{array}{l}\text { Barangay } \\
\text { Captain }\end{array}$} & \multicolumn{2}{|c|}{ Beneficiaries } & \multicolumn{2}{|c|}{$\begin{array}{l}\text { Overall } \\
\text { Value }\end{array}$} \\
\hline & Mean & QD & Mean & QD & Mean & QD & Mean & QD & Mean & QD \\
\hline 1. Lack of budget & 1.00 & VR & 1.86 & $\mathrm{R}$ & 2.82 & & 2.54 & 0 & 2.50 & 0 \\
\hline 2. Inefficient employees & 1.00 & VR & 2.00 & $\mathrm{R}$ & 2.97 & & 2.47 & $\mathrm{R}$ & 2.46 & $\mathrm{R}$ \\
\hline 3. Lack of Cooperation & 1.00 & VR & 2.21 & $\mathrm{R}$ & 2.94 & & 2.49 & $\mathrm{R}$ & 2.48 & $\mathrm{R}$ \\
\hline 4. For peace and order & 1.18 & VR & 2.14 & $\mathrm{R}$ & 3.00 & & 2.57 & $\mathrm{O}$ & 2.56 & $\mathrm{O}$ \\
\hline $\begin{array}{l}\text { 5. Lack of provision of } \\
\text { supplementary budget }\end{array}$ & 1.00 & VR & 2.14 & $\mathrm{R}$ & 3.03 & & 2.43 & $\mathrm{R}$ & 2.43 & $\mathrm{R}$ \\
\hline $\begin{array}{l}\text { 6. Lack of support from } \\
\text { the National Government }\end{array}$ & 1.00 & VR & 2.21 & $\mathrm{R}$ & 3.00 & & 2.46 & $\mathrm{R}$ & 2.45 & $\mathrm{R}$ \\
\hline $\begin{array}{l}\text { 7. Lack of Physical } \\
\text { Facilities }\end{array}$ & 1.00 & VR & 2.07 & $\mathrm{R}$ & 2.94 & & 2.41 & $\mathrm{R}$ & 2.41 & $\mathrm{R}$ \\
\hline $\begin{array}{l}\text { 8. Very low processes } \\
\text { of transacting business } \\
\text { with Municipal Officials }\end{array}$ & 1.00 & VR & 1.71 & $\mathrm{R}$ & 3.00 & & 2.40 & $\mathrm{R}$ & 2.39 & $\mathrm{R}$ \\
\hline
\end{tabular}




\begin{tabular}{rccccccccc} 
9. Lack of transparency & 1.09 & $\mathrm{VR}$ & 1.57 & $\mathrm{R}$ & 2.79 & 2.38 & $\mathrm{R}$ & 2.36 & $\mathrm{R}$ \\
10. Graft and corruption & 1.00 & $\mathrm{VR}$ & 1.57 & $\mathrm{R}$ & 2.61 & 2.26 & $\mathrm{R}$ & 2.23 & $\mathrm{R}$ \\
\hline Average & $\mathbf{1 . 0 4}$ & VR & $\mathbf{1 . 9 5}$ & $\mathbf{R}$ & $\mathbf{2 . 9 1}$ & $\mathbf{2 . 4 4}$ & $\mathbf{R}$ & $\mathbf{2 . 4 3}$ & $\mathrm{R}$ \\
\hline
\end{tabular}

* significant at .05 Alpha

Table 5 presents the perceptions of the respondents in terms of the problems encountered in the Implementation of Basic Services. Item No. 4 Peace and Order scored highest at 2.56; Lack of Budget at 2.50 or rated occasionally; and item no. 3, Lack of Transparency incurred the lowest at 2.23 qualitatively described as rarely. These findings show slight magnitude of the problems.

It can also be seen from Table 5 that, with the exception of Municipal Elective Officials who perceived all items as very rarely encountered, the rest of the groups rated the items as rarely encountered. However, this does not mean that no intervention shall be made by LGU San Mateo. There is still a need to look into the items closer especially on Lack of Budget and Peace and Order so as to avoid the elevation of these concerns.

The finding can be attributed to financial resources provided for Peace and Order and Budget Allotment which are not significant. This finding supports the study of Bueno (2011). This also coincides with the insight of Aldaba (2007) as to the "effectiveness of delivery of social services depends so much on the local budget". Therefore, the findings suggest the importance of increasing budget allocation in general in the implementation of programs and basic services.

\section{Conclusion}

Based on the summarized findings, the following conclusions were drawn. The 4 classes of respondents vary in their perceptions on the level of delivery of basic services. The respondents assessed the 7 basic services with High Implementation Level where Environmental Management Services scored the highest rank and Agriculture Service scored the lowest implementation mean. The 4 dimensions of good governance had favourable responses of very satisfactory. All basic services have a probability value of 0.000 which is less than .05. This establishes significant differences on the level of implementation of basic services. All significantly differ among the 4 groups with probability values (p-value) less than 0.05 . Therefore, the null hypothesis of no significant difference in the perceptions of the 4 groups of respondents in terms of good governance on the level of implementation of basic services is rejected. The municipality's challenges were rarely encountered in terms of implementation.

Furtheremore, the study revealed that the basic services are highly implemented. However, the areas of sustainability and viability of these programs in accordance to the needs of San Mateo citizens are desired especially in the items with lowest mean values. For Agriculture Service, since this area needs high capital and investment that the municipal government could not afford to implement and sustain, it is recommended to join forces with the Department of Agriculture, State Universities, TESDA, DOST, and those concerned institutions in order to provide financial support. Though Lack of Budget" and Peace and Order were occasionally encountered, it is still recommended to the leaders of San Mateo source more funds to finance the basic services for the general benefits of their constituents, since needs satisfaction has direct link to these items.

For Infrastructure Service, the municipal officials should allot budget for earthquake dike construction since the respondents think it is necessary. In Health Services, there should be a periodic evaluation to identify the strengths and weaknesses of the management of the RHU of San Mateo to cope with the standards prescribed by the Department of Health or other higher organizations.

Likewise, the Local Health Boards should endeavour to increase allocations for priority programs, such as medicines, medical supplies and equipment, since they are empowered to participate in budget deliberation. Environmental Management Service was sought to be sustainable yet LGU San Mateo should continually find scientific and creative interventions on waste disposals and other environment concerns. On Tourism Services, LGU San Mateo should identify potential areas to be developed as tourist attractions that will 
showcase San Mateo's best. Better yet, integrate tourism to agriculture to totally package San Mateo as an Agro-Ecological City. On Educational Support Service, partnership of schools and LGU should be evident by allotting budget to finance training and research support to teachers. Since research plays a very important role in the development of LGU, they should provide financial or scholarship assistance to research undertakings in favour of the said institution.

Since Entrepreneurship is identified as the lowest in the implementation of basic services under Social Service, then LGU San Mateo should source funds to conduct seminars and trainings along this area or to link with appropriate body to provide small and medium enterprise skills to their constituents. This may be through partnerships with SUCs, DTI, and even private institutions to educate, transfer technology, and finance the programs on this aspect. Good governance should be promoted through strategies such as ensuring high quality, efficiency, transparency, accountability, financial and physical accessibility and nondiscriminatory delivery of public services, curbing both bureaucratic and political corruption, strengthening the rule of law, and enhancing citizens' access to information and participation in governance. These all boil down to participatory governance.

\section{References}

Armstrong, G., \& Kotler, P. (2011). Marketing: An Introduction. Building Customer Relationships, 10th, 41-48, Singapore: Pearson.

Bal, P., de Lange, A., F., Jansen, P., Van der Velde, M. E.G. \& Ybema, J. (2011). Age and Trust as Moderator in the Relation between Procedural Justice and Turnover: A Large Scale Longitudinal Study. Applied Psychology: An International Review, 60 (1), 66-86. https://doi.org/10.1111/j.1464-0597.2010.00427.x

Beatson, A., Ling,. I. \& Gudergan S. (2008). Employee Behavior and Relationship Quality: Input on Customers: The Service Industries Journal, 28 (2), 211-223. https://doi.org/10.1080/02642060701842282

Bhiwajee, S. L., Munhurrun, P. R., \& Naidoo, P. (2010). Service quality in the public service: University of Technology, .International Journal of Marketing Research, (1). Retrieved on November $\quad$ 1, 2013 from http://www.bibliotheque.gouv.qc.ca/app/DocRepository/1/trouve_pour_vous_administrati on/service_quality_in_the_public_service.pdf

Baran, R,.ProfGalka,R.J.,ProfStrunk D. (2008). Marketing strategy and CRM. Principles of Customer Relationship Management.,.317-323, USA: Thomson South- Western.

Battaglia, M. (2013). Encyclopedia of Survey Research Methods. Retrieved on September 28, 2013 from http://srmo.sagepub.com/view/encyclopedia-of-survey-research- methods/n105.xml

Brilliantes, A., Jr. (2003). Innovations \& Understanding Local Governments in the Philippines, Polystar Graphics \& Multi Print Paranaque City, Philippines.

Bourgon (2007). Citizens management: Why should governments engage citizens in service and policy making? Retrieved on November $1, \quad 2013$ from http://www.oecd.org/gov/42240216.pdf

BUENO, C. F. (2011). Decentralization Policy of Local Government Units in the First District of Ilocos Sur. UNP Research Journal, 20(1), 1-1.

Carron, D. J. \& David, G. (2006). Civil servant identify at the crossroads: New challenges for public administration, International Journal of Public Sector Management, .19 (6), 543-555. https://doi.org/10.1108/09513550610685989

Cheema, S. \& Popovski, V. (2010). Building trust in government: Innovations in Governance Reform in Asia. United

Nations University Press. N. Y. Retrieved on November 2, 2013 from http://isp.unu.edu/publications/books/2010/building-trust-in-government.html

Comprehensive Development Plan of San Mateo, Isabela 2011-2016

David, M \& Heinelle, J. (2003). Managing services: Using technology to create value, McGraw-Hill/Irwin.

Edralin, D. (2000). Research Method. Business Research. De La Salle University, Manila. European Public Administration Union (2008). European Primer on Customer Satisfaction Management. Retrieved on October 29, 2013 from http:// www.eipa.eu/customer.

Fitzsimmons, J. A., \& Fitzsimmons, M. J. (2008). Service Management, 6th, NY: McGraw Hill.

Fonseca, F., Pinto, S., \& Brito, C. (2012) Service quality and customer satisfaction in public transports, 4 (2), UDK656.025.2:658.56. Retrieved on November 1, 2013 from http://www.ijqr.net/journal/v4-n2/4.pdf 
Giventer, L. (2008). Statistical Analysis for Public Administration: Multiple Regression Analysis, 328, Canada: Malloy Inc.

Gronross, C. (2007). Service Management and Marketing Customer Management in Service Competition, 3rd, England: John Wiley \& Sons, Ltd.

Groebner, D.F., Shannon, P.W., Fry, P.C., \& Smith, K.D. (2011) Business Statistics: A Decision-Making Approach, 8th, NJ: Pearson.

Gupta, N. \& Valamarthi, G. (2009). Total Quality Management, 2nd, New Delhi: McGraw Hill.

Illaamie A. (2010). IAENG International Journal of Trade, Economics and Finance, 1 (1). Retrieved on November 1, 2013 from http://www.ijtef.org/papers/8-C145.pdf Innovations in governance reform in Asia (n.d.). Trends and Innovations in Governance. Retrieved on November 1, 2013, from

http://www. unu.edu/media/publication/000/002/158/ buildingtrustingovt.pdf.

International Finance Corporation (2011). Doing business 2011: Making a difference for entrepreneurs. Retrieved on November 1, 2013 from http://www.doingbusiness.org

Ipsos, M. (2010). Public sector service satisfaction index: A report for consumer focus. Retrieved on November 1, 2013 from http://www.consumerfocus.org.uk/files/2011/10/Public-sector-service-satisfaction- index.pdf

IOSR Journal of Electronics and Communication Engineering (IOSR-JECE) e-ISSN: 2278-2834,p- ISSN: 22788735.Volume 9, Issue 1, Ver. II (Jan. 2014), PP 33-39 www.iosrjournals.org www.iosrjournals.org 33 | Page Facial Age Group Classification Jignesh Prajapati, Ankit Patel, Punit Raninga EC Department, Parul Institute of Engineering \& Technology, Limda, Vadodara, India

Ipsos, M. (2002). Public service reform: Measuring and understanding customer satisfaction. Retrieved on November 1, 2013 from http://www.mori.com/sri/public-service- reform

Jupp, V. (2006).The SAGE dictionary of social research methods. Retrieved on March 20, 2013 from http://srmo.sagepu

Kheng, L., Mahamad, O., Ramayah, T., \& Mosahab, R. (2010). Impact of service quality on customer loyalty: A study of banks in Penang, Malaysia. International Journal of Marketing Studies, 2 (2). Retrieved on November 1, 2013 from http://www.ccsenet.org/ijms

Kotler, P., \& Armstrong, G. (2008).Principles of marketing, 12th, Upper Saddle River, Pearson, N.J.

Loke, S.P., Taiwo, A., Salim, H.M., \& Downe, A. G. (2011). Service quality in a telecommunication service provider. IPEDR 11, Singapore: IACSIT Press. Retrieved on November 1, 2013 from http://www.ipedr.com/vol11/5-R00009.pdf Lovelock D. L., \& Writz, J. (2007). Services Marketing, 6th, Pearson, NJ.

Mahloane, L. (2009). An approach to service delivery in the government sector. CPUT

Theses \& Dissertations. Retrieved on November 1, 2013 from http://dk.cput.ac.za/td_cput/99 Malaluan, Maribeth. Financial Management of LGU Services in Camarines Norte.

Unpublished Masteral Thesis, University of Nueva Caceres, Naga City, 2001. Retrieved from

http://rsrlibresearch.blogspot.com/2008/02/financial-management-of-lgu-services-in-

html.

Manasan, Rosario G., Cuenca, Janet S., Celestino, Alicia B. Mobilizing LGU Support for Basic Education: Focus on Special Education Fund. Retrieved from http://www.pids.gov.ph/dp.phd?id=4954\&pubyear=2011. Manzin, M., Mrak, B. \& .Žurga, G. (2012). Quality of public services dimensions model as a basis for better customer satisfaction management. African Journal of Business Management. 6 (26), 7833-7841, doi: 10.5897/AJBM11.2528.

McLeod, S. (2008). Likert scale.Retrieved on March 14, 2013 from http://www.simplypsychology.org/likert-scale.html McNabb, C. (2007). Descriptive research methodologies. Retrieved on March 19, 2013 from http://pangea.tec.selu.edu/ cmcnabb/philosop/power.ppt

Nolledo, N. (2001). The 1991 Local Government Code, Rex Bookstore, Manila

Palmer, A. (2011). Principles of Services Marketing, London: McGraw Hill. Philippine Development Plan 2011-2016

Pizam, A. (2010). International Encyclopedia of Hospitality Management, 2nd, Retrieved on November 1, 2013 from http://books.google.com/books? Id=VyBjQQ al TxwCa print $\mathrm{sec}=$ frontcover\#v=onepage\&q\&f=false

Public sector service satisfaction index: A report for consumer focus (2010). Retrieved on November $1, \quad 2013$ from http://www.philstar.com/Article.aspx?articleId=600685\&SubCategoryId=66

Srinivasan, R. (2009). Services Marketing: The Maiau Context, 2nd, 125. New Delhi: PHI Learning Limited. Sullivan (2007). Authenticity, accuracy and reliability in the public sector: annotated bibliography. Retrieved on November 1, 2013 from http://www.interpares.org/displaya. file.cfm?doc=ip2_biblio_aar_public_sector_annotated.pdf 
State of Queensland (2010). Public perceptions of local government: Findings from the 2010 public attitudes survey. Retrieved on October 29, 2013 from http://www. www.cmc.qld.gov.au/public-sector-service-satisfaction-index.pdf

The Scottish housing regulator. (n.d). Retrieved on October 29, 2013 from a. http://www.communitiesscotland.gov.uk/stellent/groups/public/documents/webpages/sh r_howtogather-servqual.hcsp Trochim, W. (2006).Research methods knowledge base. Retrieved on March 19, 2013 from http://www.socialresearchmethods.net/kb/scallik.php

Wang, V. (2009). Do demographic characteristics patient satisfaction?. Retrieved on October 27, 2013 from Customer satisfaction: What the research tell us (2007).Center for the Study of Social Policy. Retrieved from: http://www.cssp.org/publications/constituents-co- invested-in-change/customer-satisfaction/customer-satisfaction-whatresearch-tells-us.pdf

Wright, G., \& Hyde-Hines, M. (2011). Measuring quality in public services. Retrieved on October 30, 2013 from http://www.ribm.mmu.ac.uk/symposium2011/fullpapers/MargaretHyde.pdf 